\title{
Recipe modeling and the study of the chemical composition of functional fish culinary products
}

\author{
Olga Kutina ${ }^{1}$, and Irina Korotkyh ${ }^{2 *}$ \\ ${ }^{1}$ All-Russian Research Institute, Fisheries and Oceanography, Moscow, Russia \\ ${ }^{2}$ Belgorod State National Research University, Belgorod, Russia
}

\begin{abstract}
The biochemical composition of the new fish culinary product is considered. The results make it possible to attribute the product to functional products. Compositions with a given set of nutritional value indicators were simulated by optimizing multicomponent formulations. Products are characterized by preset properties: functionality, balance of amino acid, mineral and vitamin compositions, high organoleptic characteristics due to the inclusion of original plant materials (spinach, green peas, cauliflower, eggplant, etc.) and individual methods for their preliminary preparation. The technology and the recipe are protected by a patent [1], technical standards [2], have been tested in production conditions. Product samples participated in the nomination "Innovative Product" at the international exhibition of food products, beverages and raw materials for their production PRODEXPO in 2015-2018. Development "Fish loaf" received a silver medal in 2015 .
\end{abstract}

\section{Introduction}

"Fundamentals of state power of the Russian Federation for the period up to 2020" [3], "Fundamentals of state power of the Russian Federation in the field of healthy nutrition for the period up to 2020" [4], "Doctrine of food security of the Russian Federation" [5], "Strategy improving the quality of food products in the Russian Federation until 2030" (approved by Order of the Government of the Russian Federation of June 29, 2016 No. 1364-p) [7] and the Action Plan for the implementation of the Strategy for improving the quality of food in the Russian Federation until 2030 (approved by Order of the Government of the Russian Federation of April 19, 2017 No. 738 -p) [8]. All of these documents address issues related to the creation of conditions that ensure the satisfaction of the needs of various population groups for healthy nutrition in accordance with the requirements of medical science, as well as taking into account established traditions, habits and economic conditions.

Raw fish is the most important component of a healthy diet due to the uniqueness of the source of raw materials:

- balanced amino acid composition;

- the presence of essential polyunsaturated fatty acids of the omega-3 family.

But the development of products based on fish with desired properties is difficult, because the variability of the chemical composition of fish is approximately $40 \%$, which is a fairly high indicator.

In order to expand the range of fish products, for the systematic use in the composition of food rations by all age groups of a healthy population, taking into account the rational use of fish raw materials and scientifically based nutritional standards, innovative products have been developed. The chemical composition of this product, justified from the point of view of evidencebased medicine, allows us to attribute it to a functional product.

Modeling of compositions with a given set of nutritional value indicators was carried out by optimizing multicomponent formulations.

\section{Experimental}

The following research methods were used in the analysis of the developed products:

- for laboratory research of fish products, sampling and preparation of samples was carried out according to a single technique in accordance with the requirements of GOST 7636-85 [9], GOST 31339-2006 [10];

- determination of protein content - Kjeldahl method according to GOST 25011-2017 [11];

- the amino acid composition of the proteins was determined on an AAA-835 amino acid analyzer ("Hitachi", Japan) by liquid chromatography;

- tryptophan content was determined according to GOST 32201-2013 (ISO 13904: 2005) [12];

- the vitamin content was determined by gas-liquid chromatography on a device Crystalux-4000M (Russia) on the reverse phase;

- the potassium and magnesium content was determined by the photometric method according to GOST 26449.1-85 [13];

- determination of phosphorus - according to GOST 26657-97 [14].

To solve optimization problem, we applied the computer program of the Kuban State Technological University "Generik", intended for aided design and 
calculation of multicomponent recipes of functional food products [15].

Statistical processing of individual indicators was carried out according to the Microsoft Excel-7.0 program with the determination of the average value, standard deviation and significance of differences by Student.

Experimental studies were carried out in 3-5 replicates.

\section{Results and discussion}

To obtain estimated information on the nutrient content in the composition of the modeled recipe, the material balance was used:

$$
C_{i}=\frac{\sum_{j=1}^{n} a_{i, j} \times x_{j}}{\sum_{j=1}^{n} x_{j}},
$$

where $C_{i}$ - is a mass fraction of a particular macro or microcating substance in the recipe;

$a_{i j}$ - is the value of the mass fraction of the i-th nutrient in the $\mathrm{j}$-th ingredient (component);

$x_{j}$ - mass fraction of the $\mathrm{j}$-th component in the recipe.

In the calculation process, the amino acid composition of prescription ingredients was used. From the obtained materials, data were selected that are characterized by the highest rates of desirability function (DF), which reflects the degree of balance of amino acids in product proteins.

Taking into account the restrictions imposed on the quantitative content of components set during the development of food products (their sum is accepted as a unit) and permissible deviations from the values of the mass fractions of nutrients from reference ones, it was proposed to use the Lagrange function and the equation system in the form of conditions of the Kuhn-Tucker theorem for the convex programming problem to model recipes. Its solution allows us to obtain the vector $x$ mass fractions of the recipe, the most balanced nutrient composition.

Modeling of the most balanced recipe does not always determine the highest quality of the finished food product, therefore, in most cases, not one, but a sufficiently wide range of options for the composition of the prescription composition is required for its development. For this purpose, it is proposed to divide the process of its optimization into two stages. The first is the modeling of the recipe as the definition of all possible options for the quantitative ratio of the ingredients included in it. The second is a qualitative assessment and selection of several of its most optimal options.

Harrington's desirability function was used as a generalized criterion for assessing the quality of the modeled recipe, which ensures the independence of the properties of particular indicators with different dimensions and a range of variable values, and at the same time it allows you to combine relative complex and simple unit quality criteria into one formula:

$$
Y=\sqrt[k]{\prod_{i=1}^{k}} \times p_{i}
$$

where $Y$ - is a comprehensive quality criterion;

$p_{i}-$ particular criteria (functions) of quality.

When optimizing food recipes, it is usually advisable to use the desirability function using a two-way restriction:

$$
\begin{gathered}
p_{i}=\exp \left(-\left|y_{i}\right|^{n_{c}},\right. \\
y_{i}^{\prime}=\frac{2 \times C_{i}-\left(L_{i \max }+L_{i \min }\right)}{L_{i \max }-L_{i \min }},
\end{gathered}
$$

where $C_{i}$ - is the mass fraction of the i-th nutrient (food substance) in the studied recipe;

$L_{i \min }, L_{i \max }$ - the limits of the standard value of the ith food substance.

The parameter $n_{i}$ determines the characteristic of the curve, with $n_{i} \rightarrow \infty$ the curve takes a rectangular shape.

As a result of the research, a range of fish culinary products for a healthy nutrition was developed, including the "Fish Loaf", the recipe of which is presented in

\begin{tabular}{|c|c|}
\hline $\begin{array}{c}\text { Name of the prescription } \\
\text { component }\end{array}$ & Content, \% \\
\hline Cod fish fillet & $30.0-40.0$ \\
\hline Salmon fillet & $15.0-25.0$ \\
\hline Onion & $5.0-8.0$ \\
\hline Spinach & \multirow{4}{*}{$10.0-20.0$} \\
\hline or eggplant & \\
\hline or green peas & \\
\hline or cauliflower & \\
\hline Egg & $3.5-4.5$ \\
\hline Vegetable oil & $4.0-6.0$ \\
\hline Potato starch & $2.0-3.0$ \\
\hline Table salt & $0.5-1.0$ \\
\hline Spice mix & $0.4-0.8$ \\
\hline Water & $12.0-30.0$ \\
\hline
\end{tabular}
Table 1 .

Table 1. Formatting sections, subsections and subsubsections

Features:

- functionality;

-balance of amino acid, mineral and vitamin formulations;

- high quality of organoleptic indicators.

A culinary product has been developed for systematic use in order to increase the biological value and therapeutic value of diet food. It is part of dirts built on the principle of adapting the chemical composition and energy value of the diet to individual clinical and pathogenetic features of the disease.

We compared indicators of the chemical composition of the developed culinary product with the daily requirement of an adult for food substances according to the balanced nutrition formula by A. A. Pokrovsky (Table 2). 
Table 2. Comparative indicators of the chemical composition of fish culinary products "fish loaf" with a daily requirement for them.

\begin{tabular}{|c|c|c|c|}
\hline Food substances & Daily requirement & $\begin{array}{l}\text { Contents per } 100 \mathrm{~g} \text { of fish } \\
\text { culinary product }\end{array}$ & $\begin{array}{c}\text { Contents per } 100 \mathrm{~g} \text { of fish } \\
\text { culinary product, \% of } \\
\text { daily requirement }\end{array}$ \\
\hline 1 & 2 & 3 & 4 \\
\hline Protein, $g$ & $60-100$ & $15.800 \pm 0.600$ & 20.0 \\
\hline \multicolumn{4}{|l|}{ Essential amino acids, $\mathrm{g}$} \\
\hline tryptophan & 1 & $0.234 \pm 0.039$ & 23.0 \\
\hline leucine & $4-6$ & $1.660 \pm 0.042$ & 41.0 \\
\hline isoleucine & $3-4$ & $0,644 \pm 0.056$ & 21.0 \\
\hline valine & $3-4$ & $1.061 \pm 0.090$ & 30.0 \\
\hline threonine & $2-3$ & $0.929 \pm 0.060$ & 46.0 \\
\hline lysine & $3-5$ & $2.039 \pm 0.080$ & 70.0 \\
\hline methionine & $2-4$ & $0.388 \pm 0.035$ & 20.0 \\
\hline phenylalanine & $2-4$ & $0.771 \pm 0.059$ & 38.0 \\
\hline \multicolumn{4}{|l|}{ Nonessential amino acids, $g$} \\
\hline histidine & $1,5-2$ & $1.133 \pm 0.075$ & 73.0 \\
\hline arginine & $5-6$ & $1.104 \pm 0.088$ & 22.0 \\
\hline cysteine & $2-3$ & $0.190 \pm 0.022$ & 10.0 \\
\hline tyrosine & $3-4$ & $0.712 \pm 0.062$ & 22.0 \\
\hline alanine & 3 & $1.013 \pm 0.098$ & 30.0 \\
\hline serine & 3 & $0.896 \pm 0.078$ & 30.0 \\
\hline glutamic acid & 16 & $3.353 \pm 0.020$ & 21.0 \\
\hline asparagic acid & 6 & $1.985 \pm 0.130$ & 33.0 \\
\hline proline & 5 & $0.907 \pm 0.070$ & 18.0 \\
\hline \multicolumn{4}{|l|}{ Minerals, mg } \\
\hline phosphorus & $1200-1500$ & $225.000 \pm 0.001$ & 16.7 \\
\hline potassium & $2500-5000$ & $750.000 \pm 0.001$ & 30.0 \\
\hline magnesium & $400-450$ & $67.500 \pm 0.001$ & 16.9 \\
\hline \multicolumn{4}{|c|}{ Vitamins and vitamin-like substances, $\mathrm{mg}$} \\
\hline thiamine (vitamin $\mathrm{B}_{1}$ ) & $1.1-2.0$ & $0.290 \pm 0.001$ & 19.3 \\
\hline riboflavin (vitamin $\mathrm{B}_{2}$ ) & $1.3-2.4$ & $0.310 \pm 0.001$ & 23.8 \\
\hline pyridoxine (vitamin $\mathrm{B}_{6}$ ) & $1.8-2.0$ & $0.280 \pm 0.001$ & 15.6 \\
\hline cobalamin (vitamin $\mathrm{B}_{12}$ ) & 0.003 & $0.00045+0.00001$ & 15.0 \\
\hline
\end{tabular}

\section{References}

1. O. Kutina, M. Mogil'nyj, T. Shlenskaya, and T. Sharova, Fish loaf with herbal components, Patent №2630314, Bul. 19 (2015)

2. M. Mogil'nyj (editor), Book of technical standards. Recipe book for the nutrition of workers at manufacturing enterprises and students in educational institutions of higher education (Deli plyus, Moscow, 2016)

3. The concept of long-term socio-economic development of the Russian Federation for the period up to 2020, approved by the order of the Government of the Russian Federation of November 17 (2008)

4. Fundamentals of the state policy of the Russian Federation in the field of healthy nutrition of the population for the period up to 2020 were approved by the Order of the Government of the Russian Federation of October 25 (2010)
5. Food Security Doctrine of the Russian Federation, approved by the Decree of the President of the Russian Federation of January 21, 20 (2020)

6. The development strategy of the food and processing industry of the Russian Federation for the period up to 2020, approved by the Order of the Government of the Russian Federation of April 17 (2012)

7. Food quality improvement strategy in the Russian Federation to 2030, approved by the order of the Government of the Russian Federation of June 29, (2016)

8. Action plan for the implementation of the food quality improvement strategy in the Russian Federation until 2030, approved by the decree of the Government of the Russian Federation of April 19, (2017)

9. GOST 7636-85. Fish, marine mammals, invertebrates and products of their processing. Methods of analysis, (Standartinform, Moscow, 2010) 
10. GOST 31339-2006. Fish, non-fish objects and products of their processing. Acceptance rules and sampling methods, (Standartinform, Moscow, 2007)

11. GOST 25011-2017. Meat and meat products. Protein determination methods, Moscow: Standartinform, (Standartinform, Moscow, 2018)

12. GOST 32201-2013 (ISO13904:005). Feeds, compound feeds. Method for determination of tryptophan, (Standartinform, Moscow, 2014)

13. GOST 26449.1-85. Stationary distillation desalting units. Methods of saline water chemical analysis, (Izdatel'stvo standartov, Moscow, 1986)

14. GOST 26657-97. Fodders, mixed fodders, mixed fodder raw materials. Methods for determination of phosphorus content, (Interstate Council for Standardization, Metrology and Certification, Minsk, 1998)

15. A. Zaporozhskiy, V, Zaporozhskiy, Program for computer aided design, calculation and quality assessment of multicomponent food recipes (Generic-2.0), Certificate of program for computer, $\mathbf{2 0 0 5 6 1 1 7 2 0}$

16. GOST R 55577-2013. Specialized and functional foodstuffs. Information about the distinctive signs and efficiency claims, (Standartinform, Moscow, 2014) 